\title{
Applicability of Stoic Philosophy to Character Education
}

\author{
Gita Leitlande Mg. oec., Mg. sc. pol., Bc. phil. \\ University of Latvia, Latvia \\ gitale.edu@gmail.com
}

\begin{abstract}
Character education requires an interdisciplinary approach of education, philosophy, and psychology. Philosophical school of Stoicism is well positioned to be used as an underpinning philosophical theory to reinforce and fortify the effectiveness of character education, as it resembles both virtue-based approach and shares virtues with those promoted by character education. The article contains an example of Latvia's government regulations and approach to virtue-based character education. The aim of a study is to explore how Stoic philosophy can be instrumental for educators implementing a character education approach within school education. The study was conducted using qualitative research methods, by analysing sources of Stoicism and applying them to contemporary concepts and understanding of character education. The results of the study consist of the identified seven key insights how Stoic philosophy can make a valuable contribution, supplemented by recommendations for each key insight in a form of conclusion. Stoic philosophy emphasises teaching through context, role models, and through Stoicism itself, based on an assumption of a sustained process. Since character education in schools is a growing movement, today's educators can draw ideas directly from these findings, as well as approaching character education through a lens of Stoicism.
\end{abstract}

Keywords: character education, Stoicism, values, virtues, school education.

\section{Introduction}

Schools and teachers affect the character and values of students, regardless of whether there is a deliberate intent to influence them or not. Students spend around 12 years of their lives in school, being exposed to the specific school environment, social interactions, curriculum, and values they express. "Character education is thus not optional in school - it is inevitable" (Berkowitz, Bier, 2005, ii). It is not an option for educators to choose whether to do character education or not at all, instead - whether educators choose to conduct it in "intentional, conscious, planned, proactive, organized and reflective" or "assumed, unconscious, reactive, subliminal or random" (Kristjánsson, 2013, 276) manner.

T. Lickona, who has been called "the father of modern character education" summarizes deliberate character education as follows: "it is the deliberate effort to cultivate virtue in its cognitive, emotional, and behavioural dimensions. It does so intentionally through every phase of school life, from the teacher's example to the handling of rules and discipline to the content of the curriculum to the conduct of sports" (Lickona, 2001). This interpretation of deliberate effort is used as a basis to describe character education in the article. Character refers to "that subset of personality traits that are morally evaluable and considered to provide persons with moral worth" (Kristjánsson, 2013, 270). Values are understood as ideals or goals, which are aspirational and govern our thinking and actions. While virtues are values put to use in a persistent way, "that is to say, a characteristic and tendency to be (think and act) in a certain way" (Whiting et al., 2018,3). Character education provides a framework for the inculcation of values and moral habits (developing virtues) within school education.

Even though recognizing that schools are not the only or most powerful habitat for the development of character and having some reluctance of pluralist societies to agree to any definite set of values, the character education approach within school education is a growing movement. It is fuelled by the needs of the society to promote both good individuals and good citizenship (Arthur, 2010; Citizenship education..., 2017; Ozoliņ̌š, 2010). Properly done character education is not an indoctrination into any particular political or religious doctrine, striving not for an excellent, predictable behaviour in any situation, but instead "teaching students what a morally good life consists of" (Kristjánsson, 2013, 276). In their study M.W. Berkowitz and M.C. Bier conclude that character education "does work, if effectively designed and implemented", "it affects much", and "it lasts" (Berkowitz, Bier, 2005, 19), pointing strongly to the efficacy of the undertaking of character education in schools. 
In Latvia the ideas of schools as habitats for character education are embedded within government regulations (Izglītojamo audzināšanas vadlīnijas..., 2016; Vērtības darbos..., 2019). Shortly before their approval, M. Kūle wrote: "thus far there has not been willingness to strengthen values in Latvia" (Kūle, 2016, xx). As a very welcome development, government regulations address this very issue (among other valuable notions) by defining values to be promoted within Latvian school system: life, respect, freedom, family, marriage, work, nature, culture, Latvian language, and the country. Alongside with twelve virtues: responsibility, studiousness, courage, honesty, wisdom, kindness, compassion, moderation, self-control, solidarity, justice, tolerance. Notably, the list of virtues includes four of the so-called cardinal virtues of Greco-Roman antiquity: courage, wisdom, moderation and self-control, and justice. These values and virtues are to be promoted throughout the entire school life of a student. The intention of the article is not to argue for or against one or another value, virtues or notions which are included (or not included) within government regulations, or whether it is the best solution in general, but to offer some insight how to proceed from here in the implementation phase of the character education approach within school education.

The study conducted by Latvian scholars "Understandings of Character and Virtue Education in Riga: Main Findings" (Surikova et al., 2020) demonstrates that the strongest agreement of respondents is with character education's role in improving the behaviour of students $(\mathrm{M}=5.68$, 7-point Likert scale), while the weakest agreement is with character education as an encouragement to belong to a democratic society ( $M=4.64$, 7-point Likert scale) (Surikova et al., 2020, 270). This points to a requirement to strengthen the citizenship education dimension. The article argues that it is of utmost importance to take an integrated approach, as well-balanced combination of promoting both a good individual and good citizenship provides a sound rationale for self-improvement (that is, answering not only "what", but also "why" questions). Based on study "Patriotism in Latvian Youth and Society" conducted by the National Defence Academy of Latvia, National security curriculum for $10^{\text {th }}$ and $11^{\text {th }}$ graders (currently available as a pilot project) do focus on civic patriotism (Bērzina, 2018,4), however society would benefit if good citizenship would take a more prominent role in character education in close association with stated values and virtues. Strand of research related to a holistic approach to education also supports this mode, with empirical findings suggesting that "holistic education addresses the development of an individual as a whole and as a part of a community" (Badjanova, Ilisko, 2014, 27).

Character education requires an interdisciplinary approach of education, philosophy, and psychology. K. Kristjánsson presents the case that for the model of character education to be credible and effective, it must "be underpinned by a respectable philosophical theory" (Kristjánsson, 2015, 147). Philosophical thinking behind government regulation of character education in Latvia (as an example, moreover, it is broadly shared in Anglophone countries) does follow this path as it is clearly based upon virtue-focused moral education, which derives from virtue ethics. Theoretical basis of virtue-focused character education approach within school education are usually drawn from virtue ethics representative - Aristotle. This article looks at another representative of virtue ethics from Greco-Roman antiquity, namely Stoics, to learn what insights can Stoics offer to educators introducing character education in schools.

The ultimate goal in Stoic philosophy is to achieve what Greeks called eudaimonia, which could be translated as "the attainment of a "life is well lived" or the "good life" in the holistic sense" (Whiting et al., 2018, 1). And achieving this "life is well lived" is "up to us" and . . we all have the capacity to move towards this state, regardless of our specific social context or individual character" (Epictetus, Hard, Gill, 2014, vii). It could be done through virtue, that is, the only way to have a "life is well lived" is to become virtuous. For Stoics "virtue is a form of expertise or skill, knowledge how to live well in every way, a form of knowledge that shapes the whole personality and life", which is "sometimes translated as "excellence" and doesn't have "heavy moral overtones" of a modern interpretation of English word "virtue" (Sellars, 2014, 123). To become virtuous requires a life-long process of learning, deliberate and continuous effort. Learning, working on self-improvement is thus a key tool to achieve the "life is well lived", or as Epictetus put it: "none but the educated can be free" (Epictetus, Hard, Gill, 2014, 72). Stoicism is not a theoretical endeavour, but a philosophy that requires applying its tenets in an individual's life to live with them, practice them constantly progressing to become a better person, which eventually in the process transforms personality and the individual's way of life.

Since Stoicism as a school of philosophy is two thousand plus years old, one might wonder whether Stoicism is applicable today, in the $21^{\text {st }}$ century. There has been a noticeable revival of interest in Stoicism that began 
in the last decades of the 20th century. Today we see Stoic (ethical) tenets being applied also in crossdisciplinary setting, like in psychology (as a formative concept of Cognitive-Behavioral Therapy), military service (teaching resilience to soldiers), education (Burton, 2014; Evans, 2014; Groenendijk, de Ruyter, 2009; Guenther, 2018; Holowchak, 2009; Romaneck, 2007), and environment (sustainable practices). University of Exeter is conducting a project called "Modern Stoicism", which among other things carries out research on asking does Stoicism increase well-being of those practicing Stoicism and does its effects last. After eight years of research, the results so far convincingly show that there are indeed an increase in satisfaction with the life of respondents (for example, by 11,5\% during the Stoic Week 2019), but succeeding even better in the reduction of negative emotions (by $17 \%$ ) and anger (by $10 \%$ ) (Sadler, 2020b).

The aim of the study is to explore how Stoic philosophy can be instrumental for educators implementing a character education approach within school education.

\section{Methodology}

The study was conducted using a qualitative research method, by analysing sources of Stoicism (primary and secondary) and applying them to contemporary concepts and understanding of the character education approach within school education. Primary sources on Stoicism are translations of original texts of Roman Stoics - Seneca (4 BCE - 65 CE), Hierocles (first half of the second century CE), Epictetus (50 - $135 \mathrm{CE})$, and Marcus Aurelius (121 - 180 CE), secondary sources on Stoicism include contributions (commentary, research, analysis, interpretations) by contemporary (early $21^{\text {st }}$ century) scholars and practitioners of Stoicism, relevant to the aim of the study. Sources on character education are a combination of contemporary (early $21^{\text {st }}$ century) scholarship on the issue (mainly Anglophone countries) as well as Latvian scholarship and, where applicable, governmental regulations.

Following the aim of the article, a research question is: what specific worthwhile insights could be identified while analysing sources of Stoicism, in the light of their applicability to the character education approach within school education? Scope: purpose of the article is not to lay out in a systematic way or to explain Stoic teaching itself, nor to discuss the divergence of views and interpretations within Stoicism. Even though the article singles out government regulations in Latvia as a particular example, results of the study could be applied both to the character education solutions in Latvia and wherever else virtue-focused character education approach within school education is being carried out.

\section{Results and Discussion}

The results of the study consist of the identified seven key insights (outlined below) how Stoic philosophy can make a valuable contribution to educators implementing a character education approach within school education.

\section{Educators can help themselves}

There is no lack of challenges, uncertainties, and stress teachers and school administration face on a daily basis. "There will be people (staff, children, governors, parents) who will test your tolerance and patience ... It is an important quality to remain calm and positive and be resilient" (Sadler, 2020a). Before being able to apply character education to students, teachers and staff should first focus on themselves, their own mental fortitude and managing emotions. Marcus Aurelius insists that whatever anyone around them does or says, they must be emerald and keep their colour (Aurelius, Moore, Silverthorne, 2008, 85), inviting teachers to be able to keep unscathed their "ruling centre", as Stoics would say, during the challenges of the school day. Stoics, to be able to live by their tenets, developed practical tools (or "spiritual exercises") to be applied in their way to progressing towards virtuous persons.

Conclusions: The following Stoic tools seem to be the most valuable for educators themselves to apply in their daily school life, to prepare better for challenges and uncertainties:

1.1. The first tool is to observe a distinction proposed by Epictetus: "some things are within our power, while others are not" (Epictetus, Hard, Gill, 2014, 287). This is an appeal to foremost clearly distinguish what is in one's power, and then worry about and put the best effort only in those things that are in one's power. An example: "teachers have no control over the student's attitudes towards learning, some but not complete control over student learning itself, and complete control over what we teach and how we teach it" (Burton, 2014, 121). Consider this 
parable of the subsequent Stoic perspective facing students' attitudes towards learning: “our job is similar like raking leaves in a high wind. ... If the leaves scatter as we work, that is ultimately their business. Our disappointment or frustration is irrelevant" (Harding, 2015).

1.2. Practicing so-called pre-meditation or negative visualisation, that is, anticipating challenges which do happen daily. Marcus Aurelius suggests to begin each morning with reminding oneself, that today one will meet all kinds of people with less than decent behaviour: ungrateful, arrogant, unsocial and the like (Aurelius, Moore, Silverthorne, 2008, 33). Therefore, when the challenges do come, they don't come as a surprise, disturbing one's "ruling centre". "In short, educators need to be rational pessimists and expect more will go wrong than right" (Harding, 2015).

1.3. Evening reflection or writing of a (moral) diary. Seneca advised to reflect each evening on how the day went, as an important element of an individual's ethical development, by scrutinizing one's own thoughts, emotions and deeds during the day, asking, what went well, what went wrong, and what could be improved, done differently? Recent research on teachers' diary writing, which produced some encouraging results in improving individual teacher wellbeing, supports this approach (Kelly, 2020).

\section{Educators (and others) as role models}

Stoics recognized the power of example, that "thinking about the sage, and taking him as exemplary, helps to give the direction my ethical progress" (Annas, 2008, 13-14). This is also supported by contemporary research that providing models and mentors works well in character education (Berkowitz, Bier, 2005, 18). Ancient Stoics had a concept of a sage, the ideally virtuous person to look up to strive for. For Stoics, sage was not detached from an ordinary life. On the contrary, "the sage will take full part in everyday life. He will marry and have a family. . . . Moreover, not only does the sage live an embedded life, he should do so" (Annas, 2008, 18). To be virtuous does not mean to escape everyday life, instead it is the conduct of life in a right, exemplary way by properly applying virtues. As for real-life teachers who are not yet sages, Stoics strongly insist to align one's deeds with one's words. Seneca has these harsh words to say on the issue: "I hold that no man has treated mankind worse than he who ... lives in a different manner from that which he advises. . . . A teacher like that can help me no more than a sea-sick pilot can be efficient in a storm" (Seneca, 2013, 443). Conclusions:

2.1. Integrity of pedagogues themselves in character education is essential. Thus, to "become models for good personhood and good citizenship" (Holowchak, 2009, 167), educators should be encouraged and supported so "they persevere in improving themselves and aim to develop a proper moral disposition" (Groenendijk, de Ruyter, 2009, 89).

2.2. There is a need for an ideal (sage) to strive for, preferably a live example to reinforce educational effects, and to show, that (1) it is possible to achieve, and (2) to have a model how to conduct oneself (of course, not being mythical persons they will have their own flaws). Epictetus as his inspiration uses Socrates. Modern Stoics recognise that students today need contemporaries and diversity as sources of their inspiration, not only emperors (such as Marcus Aurelius) and those made of marble (like Socrates). This is very situational, and each community would need to come up with their own role models. In Latvia, for example, these could include former president Vaira Vīke-Freiberga and musician Renārs Kaupers.

\section{Virtue-based character education is a life-long process}

Applying virtue to everything one does is a continuous, never-ending process. For Stoics "there is no point when we can say - well, that was hard work, but I'm finally there; now I'm brave (generous, tactful or whatever)" (Annas, 2016). Seneca says, "as long as you live, keep learning how to live" (Seneca, 2013, 233), and that is one of the key concepts for Stoics - persistent ethical development. Because "nothing great comes into being all at once" (Epictetus, Hard, Gill, 2014, 36), one should keep working on improving oneself towards "whole-hearted ethical engagement or complete integrity" (Epictetus, Hard, Gill, 2014, xv-xvi). Stoics call them progressors. "So where is the progress to be found? ... Putting his guiding principles into action in relation to anything that he has to deal with . . - this, then, is the person who is truly making progress" (Epictetus, Hard, Gill, 2014, 12). All this effort has a worthy aim, which is "to give your life an overall structure and sense of priority in line with the Stoic view of happiness" (Epictetus, Hard, Gill, 2014, $\mathrm{x}$ ), that is, the "life is well lived". Conclusions: 
3.1. Approach virtue-based character education as a life-long process. One should prepare for a long run (1) individually, (2) as a school community, and (3) government collectively. In the true spirit of virtue-based learning, Latvia's government regulations already envisage the notion of life-long learning. This policy should be sustained for at least a decade to have a real impact on students and citizens.

3.2. Applying character education as a life-long process also means to ensure age-appropriate virtuebased learning in all stages of education - from nurseries, throughout all (and every) school years, and unto universities.

\section{Virtues form an inseparable set}

Stoic core virtues - courage, justice, self-control, and wisdom - are interdependent and could not be treated separately "because the correct exercise of any one virtue depends on possessing and exercising the others too" (Gill, 2015). Either one has all of them or none. Courage alone, for example, could be performed in a non-virtuous way by a gang of thieves. One cannot today be just to one group of people and the next day unjust to all others - it is not a virtuous person (Kūle, 2016, 215). Stoicism demands that exercising virtues should become a way one lives all her life, applying them to everything one does. "We tend to think that we are pretty good people because in some areas of life we are good - generous, say, while conveniently forgetting that in other areas we aren't - we're disloyal, say. No, say the Stoics, you are virtuous (or not) as a whole" (Annas, 2016). In addition, Stoicism affects not only one's knowledge (knowing what is right) and deeds (doing the right thing for the right reasons), but also "shape the personality as a whole, including emotions and desires" (Gill, 2015). This comprehensive mode is the strength of virtue-based ethics in general and Stoicism in particular, and, very likely, the reason why virtue-focused moral education is preferred to character education.

The conclusion: When teaching virtues at school (even though a slightly different set of virtues than Stoics'), the principle, that they should be approached as a package (observing all of them, not singling out only one or few) to have a well-rounded person (a fully virtuous person, Stoics would say), still holds. One should aim high (to become a sage or resembling another respectable role model, not the main gangster of the town) to attain excellence (as another translation of virtue) and the "life is well lived".

\section{The need for a broader context, complete worldview}

Ethics (in this case - values and virtues) alone is neither convincing, nor sufficient to justify life-long rigorous work on self-improvement. To live a life of conscious choices, integrity, and reflection, an individual must be able to convincingly explain her reasoning, why she acts and thinks in one or another way. Roman Stoics who were quite ignorant of most of other parts of Stoic philosophy (what they called physics and logic), nonetheless recognised that "studying just the ethical part of philosophy will not be adequate for a full understanding even of ethics" (Annas, 2007, 61). For Stoics it is the logos that provides the structure (and order) to the world. Everything exists as part of the one harmonious whole. Stoic "physics" provides a framework of worldview and "why" answers for Stoic ethics: like "why" one should respect other humans, or why humans have diverse destinies. J. Annas argues that Stoics convincingly demonstrate that a larger scheme "appeals in a deeper and more transformative way than virtue and happiness alone ever could" (Annas, 2007, 72), by providing an "integrated picture" (Annas, 2007, 63) and being "more motivationally powerful" (Annas, 2007, 71). "Thus ethics is better understood and more stable in the agent's psychology when integrated" (Annas, 2007, 71) within the complete worldview. Although in character education focus is on the individual and work on self, yet for a completely developed personality it is important to be aware of one's place and role within more broadly constructed worldviews. This is a rationale to focus in character education not only on a good individual, but also on good citizenship, to some extent in line with what M. Kūle in her monograph "The Way Things Ought to Be. Etudes on Knowledge and Values in Latvia Today" argues for the benefits of the vertical hierarchy of values. Conclusions:

5.1. Teaching only selected virtues and values without a rationale why they are essential, how they relate to each other and not constructing a systematic worldview where they would have an integral role to play, is not the most efficient approach to achieve reliable and lasting results. Seneca says: "as leaves cannot flourish by their own efforts, but need a branch to which they 
may cling and from which they may draw sap, so your precepts, when taken alone, wither away; they must be grafted upon a school of philosophy" (Seneca, 2013, 384).

5.2. Currently a (captivating) narrative either for individual virtues and values, or a collection of them is somewhat lacking in the explanatory literature for the government regulations in Latvia. It would be beneficial to organize a systematic worldview out of those ideas, to boost their coherence and relevance. The following proposals (insights no 6 and 7) detail this approach.

\section{Being part of the community as a framework for virtues and values' narrative}

Context in which selected values and virtues could be incorporated to form a narrative of a structured worldview, is the notion that an individual is part of something bigger (a larger scheme). And that one's own "life is well lived" although an important goal, is not achieved in isolation from others. Stoics recognized this aspect in two different approaches from the "physics" point of view. One is parable that we are all part of the same body, thus having different roles (hand or head, for example) but all working for the same purpose, all interrelated. The second is the notion that all humans share reason (a fragment of God in each of us), therefore humans should respect each other as equals. Hierocles developed circles of moral concern based on these concepts (all interrelated and all equal) to show how Stoics get from focusing on self-improvement to the concept of care and responsibility for others. It starts with the self and then spreads to close family, because attachment and responsibility to it is natural. From a close family it proceeds to other relatives, neighbours, countryman till all humans are included, since there is no reasonable stopping line in between those communities (Ramelli, 2009, 91). The significance of being part of the community aspects in the context of character education is recognised also by modern scholars and practitioners, like "self-serving image ... is ... misplaced" (Whiting et al., 2018, 7), "moral education brings an understanding that the enjoyment of freedom for ourselves involves the recognition that it is exercised with others and not in isolation" (Ozolinšs, 2010, 414), and "juveniles not only want to belong, but has a necessity to belong" (Auziņš, 2019, 30). That is why a well-balanced and holistic approach between the two objectives of promoting both good individual and good citizenship is desired. Citizenship education is understood as a means "to help individuals realise that they are part of a community or, to be more precise, a set of communities ranging from narrower communities at the local level to wider ones at the national and global levels" (Citizenship education..., 2017, 19), and "communitarian types of citizenship encourage citizens to view themselves as an integral, if not organic, part of the polity and to participate actively in it" (Citizenship education at..., 2017, 20). While civic patriotism is "constructively critical and active participation in civic processes with the goal to promote the common good, well-being and development of country and compatriots" (Bērziņa, 2018, 9). These definitions emphasize active participation and contribution to the community.

The conclusion: When formulating individual goals and ambitions, as well as striving for durability of virtuous individuals, it is highly beneficial to have an integrated vision of good individual and good citizenship, with clear individual's role and contribution to the community (set of communities). Awareness of being part of something bigger, as well as active participation and contribution to common good, makes a substantial difference towards the success of character education. For example, it is not only love for one's country, but also a mindset of what one can actively contribute to one's country, what is one's responsibility regarding successes and the direction where the country is headed (it is especially relevant for smaller countries). The same would apply to all kinds of communities - from family and local community to global outlook on humanity and the planet (care for sustainable development, environment), as it would inevitably involve relations with and respect to others.

\section{Teaching Stoicism (and philosophy in general) in schools and colleges}

To learn systems of philosophical thought is advantageous in two respects. First, by introducing and practicing philosophical ways of thinking (to be able to form structured belief systems). And second, they offer specific contexts, worldview systems, that could be personalized as frameworks for values and virtues. That is why youth (teenagers) and college students would benefit if their character education would be supplemented by learning philosophy (including Stoicism) itself. For example, M. Holowchak describes Stoic model of education as "distinguishable by these features: education as self-knowing, the need of logic and critical thinking for informed decision-making, learning as a preparation for life" (Holowchak, 2009, 167), mindsets that could certainly be helpful for students. Each student of Stoicism brings back one's own favoured tenets and practical tools ("spiritual exercises"), like being able to deal 
with setbacks, enjoying what one already has, learning to manage one's unreasonable emotions, and not to put too much of value on external things.

The conclusion: To teach Stoicism (and history of philosophy in general) in schools and colleges to all students. Stoicism is well positioned to be taught to reinforce and fortify the effectiveness of character education, as it resembles both virtue-based approaches, shares the virtues themselves with character education and provides a completely structured worldview as an example and source of inspiration.

\section{Conclusions}

The study has identified seven key insights how Stoic philosophy can make a valuable contribution to educators implementing character education approach within school education, supplemented by recommendations for each key insight in the form of conclusion. The study shows that Stoicism does have valuable ideas to offer to educators, and by no means this represents an exhaustive list of possible insights. Stoic approach emphasises teaching through context, role models, and through Stoicism itself. Since character education approach within school education is a growing movement, today's educators can draw direct inspiration and ideas from these findings, as well as approaching character education through the lens of Stoicism. Deliberate approach to character education takes considerable time to have an effect. It starts with instructing and supporting teachers, developing an appropriate environment in the school, up to gradually settling into students' mindsets and behaviours. That is why, if undertaken, character education approach should be sustained over the years, to bring anticipated results. It would be worthwhile in future research to refine the theoretical rationale of the concepts of good individual and good citizenship in the context of character education, and to clarify the correlation between them.

\section{Bibliography}

1. Annas J. (2007). Ethics in Stoic Philosophy. Phronesis, 52(1), 58-87. Retrieved from http://www.jstor.org/stable/4182824

2. Annas J. (2008). The Sage in Ancient Philosophy. In F. Alesse, F. Aronadio, M.C. Dalfino, L. Simeoni, E. Spinelli (Eds.), Anthropine Sophia: Studi difilologia e storiografia filosofica in memoria di Gabriele Giannantoni. Naples: Bibliopolis, 11-27. (in Italian)

3. Annas J. (2016). Is Stoic Virtue as Off-Putting as it Seems? Retrieved from: https://modernstoicism.com/is-stoic-virtue-as-off-putting-as-it-seems-by-julia-annas/

4. Arthur J. (Ed.). (2010). Citizens of Character: New Directions in Character and Values Education. UK and USA: Imprint Academic.

5. Aurelius M., Moore J. (Ed.), Silverthorne M. (Ed.). (2008). The Meditations of the Emperor Marcus Aurelius Antoninus. Indianapolis: Liberty Fund.

6. Auziņš A. (2019). "Mana Latvija " - pazìt, mīlèt, rūpêties ["My Latvia" - to know, to love, to care for]. Skola2030 ziņas, 9, 27-30. Retrieved from http://skola2030.lv/admin/filemanager/files/2/nr_9.pdf (in Latvian)

7. Badjanova J., Ilisko Dz. (2014). Holistic philosophy based teaching approaches in Latvian primary schools: Primary education teachers' view. In V. Dislere (Ed.), The Proceedings of the International Scientific Conference Rural Environment. Education. Personality (REEP), 7. Jelgava: LLU, 22-28. Retrieved from https://llufb.llu.lv/conference/REEP/2014/Latvia-UnivAgricult-REEP-2014proceedings-22-28.pdf

8. Berkowitz M.W., Bier M.C. (2005). What Works in Character Education: A research-driven guide for educators? Washington D.C.: Character Education Partnership.

9. Bērziņa I. (2018). Patriotisms Latvijas jauniešu vidū un sabiedrībā [Patriotism in Latvian Youth and Society]. Rīga: Latvijas Nacionālā aizsardzības akadēmija. Retrieved from: https://www.researchgate.net/publication/328414936_Patriotisms_Latvijas_jauniesu_vidu_un_sa biedriba (in Latvian)

10. Burton M. (2014). Stoic Teaching and Stoic Control. In P. Ussher (Ed.), Stoicism Today: Selected Writings, 1. CreateSpace Independent Publishing Platform, 119-121.

11. Citizenship education at school in Europe - 2017. Eurydice Report. (2017). European Commission/EACEA/Eurydice. Luxembourg: Publications Office of the European Union. doi: $10.2797 / 536166$ 
12. Epictetus, Hard R. (Ed.), C. Gill (Ed.). (2014). Discourses, Fragments, Handbook ( ${ }^{\text {rd }}$ ed). Oxford University Press.

13. Evans J. (2014). Getting Practical Philosophy into the Classroom. In P. Ussher (Ed.), Stoicism Today: Selected Writings, 1. CreateSpace Independent Publishing Platform, 122-127.

14. Gill C. (2014). Introduction. In Epictetus, Discourses, Fragments, Handbook, translated by R. Hard, with an Introduction and Notes by C. Gill. USA: Oxford University Press, vii-xxvii.

15. Gill C. (2015). What is Stoic Virtue? Modern Stoicism. Retrieved from: https://modernstoicism.com/what-is-stoic-virtue-by-chris-gill/

16. Groenendijk L.F., de Ruyter D.J. (2009). Learning from Seneca: a Stoic perspective on the art of living and education. Ethics and Education, 4(1), 81-92. doi: 10.1080/17449640902816277

17. Guenther L. (2018). I Must Be Emerald and Keep My Color: Ancient Roman Stoicism in the Middle School Classroom. Harvard Educational Review, 88(2), 209-226. doi: 10.17763/19435045-88.2.209

18. Harding M. (2015). Stay Stoic, Teacher! Modern Stoicism. Retrieved from: https://modernstoicism.com/the-stoic-teacher-by-mark-harding/

19. Holowchak M.A. (2009). Education as Training for Life: Stoic teachers as physicians of the soul. Educational Philosophy and Theory, 41(2), 166-184. doi: 10.1111/j.1469-5812.2007.00384.x

20. Izglītojamo audzināšanas vadlīnijas un informācijas, mācību līdzekḷu, materiālu un mācību un audzināšanas metožu izvērtēšanas kārtība [Guidelines for the Upbringing of Learners and the Procedure for Evaluating Information, Teaching Aids, Materials and Teaching/Learning and Upbringing Methods]. (2016). Retrieved from https://likumi.lv/ta/id/283735 (in Latvian)

21. Kelly L. (2020). Reclaiming teacher wellbeing through reflective diary-writing. Impact, Summer 2020(9), 19-22 Retrieved from: https://research-information.bris.ac.uk/en/publications/reclaimingteacher-wellbeing-through-reflective-diary-writing

22. Kristjánsson K. (2013). Ten Myths About Character, Virtue and Virtue Education - Plus Three Well-Founded Misgivings. British Journal of Educational Studies, 61(3), 269-287. doi: 10.1080/00071005.2013.778386

23. Kristjánsson K. (2015). Aristotelian Character Education. London: Routledge.

24. Kūle M. (2016). Jābūtības vārdi. Etīdes par zināšanām un vērtībām mūsdienu Latvijā [The Way Things Ought to Be. Etudes on Knowledge and Values in Latvia Today]. Rīga: Zinātne. (in Latvian)

25. Lickona T. (2001). What is Effective Character Education? Retrieved from: https://wicharacter.org/wp-content/uploads/What-is-Effective-Character-Ed-Stonybrook-debateby-Thomas-Lickona.pdf

26. Ozoliņš J.T. (2010). Creating Public Values: Schools as moral habitats. Educational Philosophy and Theory, 42(4), 410-423. doi: 10.1111/j.1469-5812.2008.00491.x

27. Ramelli I. (2009). Hierocles the Stoic: Elements of Ethics, Fragments, and Excerpts. Atlanta: Society of Biblical Literature.

28. Romaneck G.M. (2007). Reading the stoic Epictetus: a manual for leading. International Journal of Leadership and Education, 10(2), 227-232. doi: 10.1080/13603120601097454

29. Sadler G. (2020a). Stoic Leadership for Headteachers by Jim Mepham. Retrieved from: https://modernstoicism.com/stoic-leadership-for-headteachers-by-jim-mepham

30. Sadler G. (2020b). Stoic Week 2019 Report Part 3: Impact of doing Stoic Week Tim LeBon. Retrieved from: https://modernstoicism.com/stoic-week-2019-report-part-3-impact-of-doingstoic-week-tim-lebon

31. Sellars J. (2014). Stoicism. London and New York: Routledge.

32. Seneca L.A. (2013). The Complete Moral Letters to Lucilius. Ottawa: Stoici Civitas Press.

33. Surikova S., Pigozne T., Fernández-González M.J., Stokenberga I. (2020). Understandings of Character and Virtue Education in Riga: Main Findings. In V. Dislere (Ed.), The Proceedings of the International Scientific Conference Rural Environment. Education. Personality (REEP), 13. Jelgava: LLU, 266-273. doi: 10.22616/REEP.2020.032

34. Vērtības darbos un vārdos [Values in Deeds and in Words]. (2019). Skola2030 ziņas, 9. Retrieved from: https://www.skola2030.lv/lv/jaunumi/zinu-izdevums/vertibas-darbos-un-vardos (in Latvian)

35. Whiting K., Konstantakos L., Misiaszek G.W., Simpson E., Carmona L.G. (2018). Education for the Sustainable Global Citizen: What Can We Learn from Stoic Philosophy and Freirean Environmental Pedagogies? Education Sciences, 8(4), 204. doi: 10.3390/educsci8040204 